\title{
PENERAPAN MODEL PEMBELAJARAN PROBLEM BASED LEARNING UNTUK MENINGKATKAN HASIL BELAJAR PPKn PADA SISWA KELAS XI, SMKN 1 SUKAWATI GIANYAR
}

\author{
Dw. Pt. Raka Tista, S.Pd. \\ SMKN 1 Sukawati Gianyar, Bali \\ Email: rakatista123@gmailcom
}

\begin{abstract}
Abstrak
Penelitian ini bertujuan untuk meningkatkan prestasi belajar siswa Civic (demokrasi) dengan menerapkan model pembelajaran berbasis masalah. Subjek penelitian adalah 21 Siswa Kelas IV. Jenis penelitian ini adalah penelitian tindakan kelas. Data diperoleh dengan menggunakan metode tes. Data yang diperoleh dalam penelitian ini selanjutnya dianalisis menggunakan metode deskriptif kuantitatif. Hasil yang diperoleh pada siklus I adalah skor rata-rata siswa yaitu 70,48 dengan persentase $70,48 \%$ yang termasuk dalam kategori cukup. Pada siklus kedua, rata-rata skor 84,05 dengan persentase 84,05\% yang termasuk dalam kategori tinggi. Kenaikan rata-rata sebesar 13,57\%, yang menunjukkan bahwa penerapan model pembelajaran berbasis masalah dapat meningkatkan prestasi belajar mahasiswa (civil society).
\end{abstract}

Kata kunci : model problem based learning, hasil belajar, PKn.

\begin{abstract}
This study was aimed to improve the students' Civic (democracy) learning achievement after applying the problem based learning model. The subjects of research were 21 students of the fourth grade. The type of this research is a class room action research. The data is obtained by using the test method. Once the data obtained in this research, further data were analyzed using descriptive quantitative method. The results obtained in the first cycle is the students' average score reached to 70.48 and the students' average percent reached to $70.48 \%$ are included in the category of medium level learning outcomes. In the second cycle, it reached 84.05 and the average percent reaches to $84.05 \%$ are included in the category of high-level learning outcomes. The average increase of $13.57 \%$, which means that the implementation of problem based learning models can improve the students' Civic (democracy) learning achievement.
\end{abstract}

Keywords: problem based learning, learning achievement, Civic

\section{Pendahuluan}

Penyelenggaraan pendidikan di sekolah yang melibatkan guru sebagai pendidik dan siswa sebagai peserta didik diwujudkan dengan adanya interaksi belajar mengajar atau proses pembelajaran. Dalam konteks penyelenggaraan ini, guru merencanakan kegiatan pembelajaran secara sistematis dan berpedoman pada seperangkat aturan dan rencana tentang pendidikan yang dikemas dalam bentuk kurikulum.

Kurikulum 2006 yang disempurnakan menjadi Kurikulum Tingkat Satuan Pendidikan (KTSP) lebih bersifat inovatif dan ekspresif. Pembelajaran PKn dengan standar kompetensi: mengungkapkan pikiran, perasaan, informasi dan fakta secara tertulis dalam bentuk ringkasan, laporan serta kompetensi dasar: demokrasi. Kurikulum ini memberi peluang bagi pendidik dan anak didik untuk melakukan terobosan-terobosan dalam proses pembelajaran. Di samping meningkatkan daya saing di antara siswa, kurikulum ini memberi kesempatan pendidik untuk berkreasi dalam mengembangkan materi pembelajaran. Proses pembelajaran yang mengacu pada kompetensi berdampak pada kelulusan. Keberhasilan pembelajaran dengan KTSP sangat ditentukan oleh institusi pendidikan, sarana prasarana, kondisi siswa, lingkungan pendidikan serta guru yang profesional.

Di SMK diperlukan pengembangan pengetahuan khususnya dalam pembelajaran PKn, karena pembelajaran PKn akan digunakan sampai ke jenjang pendidikan yang paling tinggi sehingga anak akan lebih mudah untuk mengikuti pembelajaran PKn lebih lanjut. Untuk itu guru sekolah menengah sebagai pendidik harus dapat mengatasi kendala dalam kesulitan belajar PKn. Namun sebagian besar siswa berpendapat bahwa pelajaran Pendidikan Kewarganegaraan (PKn), merupakan pelajaran yang membosankan. Hal ini disebabkan oleh proses pembelajaran yang sering kali digunakan adalah pembelajaran dengan memberikan uraian teori secara panjang lebar. Dengan pembelajaran seperti itu, para guru akan mengontrol secara penuh materi serta proses pembelajarannya. Akibatnya, proses pembelajaran PKn, di kelas sulit untuk dipahami penerapannya baik 
teori maupun konsep-konsepnya sehingga menyebabkan terkesan kurang menarik pada siswa dan menyebabkan hasil belajar PKn belum menunjukkan hasil yang memuaskan.

Berdasarkan hasil refleksi awal diperoleh data bahwa hasil belajar PKn pada siswa SMKN Sukawati, masih rendah. Hal ini tampak dari hasil belajar PKn pada siswa yang memperoleh nilai 65 belum mencapai $85 \%$. Dari 21 orang siswa hanya 8 orang yang memenuhi Kriteria Ketuntasan Minimal (KKM). Berdasarkan masalah tersebut, maka dicoba untuk menerapkan model Problem Based Learning (PBL) dengan harapan dapat meningkatkan hasil belajar PKn pada siswa SMKN 1 Sukawati.

Problem Based Learning ( $P B L$ ) adalah pengajaran yang dirancang berdasarkan masalah dengan tujuan siswa dapat menyusun pengetahuan sendiri, mengembangkan penyelidikan (inkuiri), mengembangkan keterampilan berpikir tingkat tinggi, keterampilan pemecahan masalah, kemandirian, kepercayaan diri, serta memperoleh pengetahuan dan konsep yang esensial dari materi pelajaran.

Menurut Arends (dalam Trianto, 2010:92), "problem based learning merupakan suatu pendekatan pembelajaran yang menuntut siswa mengerjakan permasalahan yang autentik dengan maksud untuk menyusun pengetahuan mereka sendiri, mengembangkan inkuiri dan keterampilan berpikir lebih tinggi, mengembangkan kemandirian dan percaya diri". Pembelajaran tidak begitu banyak pada apa yang sedang dilakukan siswa (perilaku mereka), melainkan kepada apa yang mereka pikirkan (kognitif mereka) pada saat mereka melakukan kegiatan itu.

Menurut Dewey (dalam Trianto, 2010:91), "problem based learning adalah interaksi antara stimulus dan respons, merupakan hubungan antara dua arah, belajar dan lingkungan". Lingkungan memberikan masukan kepada siswa berupa bantuan dan masalah sedangkan sistem saraf otak berfungsi menafsirkan bantuan itu secara efektif sehingga masalah yang dihadapi dapat diselidiki, dinilai, dianalisis, serta dicari pemecahannya dengan baik. Pengalaman siswa yang diperoleh dari lingkungan akan menjadikan kepadanya bahan dan materi guna memperoleh pengertian dan bisa dijadikan pedoman dan tujuan belajarnya.

Menurut Dutch (dalam Amir, 2007:21) "problem based learning adalah metode pendidikan yang mendorong siswa untuk mengenal cara belajar dan bekerja sama dalam kelompok untuk mencari penyelesaian masalah-masalah di dunia nyata". problem based learning menyiapkan siswa untuk berpikir secara kritis dan analitis, serta mampu untuk mendapatkan dan menggunakan secara tepat sumber-sumber pembelajaran.

Berdasarkan penjelasan tersebut, problem based learning dapat diartikan sebagai suatu model pembelajaran yang mendorong siswa untuk mengenal cara belajar dan bekerja sama dalam kelompok untuk mencari penyelesaian masalah-masalah di dunia nyata. Stimulus masalah digunakan untuk mengaktifkan keingintahuan siswa sebelum mulai mempelajari suatu subjek. Problem based learning menyiapkan siswa berpikir kritis dan analitis, serta mampu untuk mendapatkan dan menggunakan secara tepat sumber-sumber pembelajaran.

Menurut Rusyan (1992) mengemukakan beberapa keuntungan dan kekurangan model Problem Based Learning sebagai berikut. Keuntungan Problem Based Learning (1) cara ini dapat membuat belajar lebih relevan dengan kehidupan, (2) membiasakan siswa menghadapi dan memecahkan masalah secara terampil, (3) merangsang perkembangan kemampuan berpikir secara kreatif dan menyeluruh. Sedangkan kekurangan Problem based learning (1) sulit menentukan masalah yang tingkat kesulitannya sesuai dengan tingkat kemampuan siswa. (2) memerlukan waktu yang lama dalam memecahkan masalah.

Berdasarkan kelemahan yang dipaparkan di atas, hal penting yang harus diketahui adalah bahwa guru perlu memiliki seperangkat aturan yang jelas agar pembelajaran dapat berlangsung tertib tanpa gangguan, dapat menangani perilaku siswa yang menyimpang secara cepat dan tepat, juga perlu memiliki panduan mengenai bagaimana mengelola kerja kelompok. Selain itu yang tidak kalah pentingnya, guru harus menyampaikan aturan, tata krama, dan sopan santun yang jelas untuk mengendalikan tingkah laku siswa ketika mereka melakukan penyelidikan di luar kelas.

Selain itu guru hendaknya menggunakan model problem based leaning ini disesuaikan dengan materi yang akan diajarkan, sehingga akan memperoleh hasil yang optimal serta dapat meningkatkan hasil belajar siswa.

Problem based learning biasanya terdiri dari lima tahapan utama yang dimulai dengan guru memperkenalkan siswa dengan suatu situasi masalah dan diakhiri dengan penyajian dan analisis hasil kerja siswa. Adapun sintaks PBL sebagai berikut. (1) orientasi siswa kepada masalah, (2) mengorganisasi siswa untuk belajar, (3) membimbing penyelidikan individual maupun kelompok, (4) mengembangkan dan menyajikan hasil karya, (5) menganalisis dan mengevaluasi proses pemecahan masalah.

Berdasarkan latar belakang dan kajian teori, maka tujuan yang ingin dicapai dalam penelitian ini adalah untuk mengetahui peningkatan hasil belajar PKn pada siswa SMKN Sukawati tahun pelajara 2015/2016 setelah penerapan model pembelajaran problem based learning .

\section{Metode Penelitian}

Jenis penelitian ini adalah penelitian tindakan kelas (PTK). Penelitian tindakan kelas merupakan "suatu pencermatan terhadap kegiatan belajar. Sebuah tindakan, yang sengaja dimunculkan dan terjadi dalam sebuah kelas 
secara bersamaan" (Arikunto, 2007:3). Penelitian ini mengambil tempat di Sekolah Menengah Kejuruan Negeri 1, pada siswa kelas XI.

Pelaksanaan penelitian ini dilakukan secara bertahap atau multi siklus. Tujuan dilaksanakannya multi siklus adalah untuk menemukan suatu tindakan terbaik sehingga permasalahan yang ditemukan dapat diatasi. Setiap siklus terdiri atas empat tahapan yaitu (1) perencanaan, (2) pelaksanaan, (3) pengamatan dan evaluasi dan (4) refleksi.

Berhasil tidaknya penelitian ini dilakukan dapat diketahui berdasarkan data-data yang diperoleh. Pemerolehan data dapat dilakukan dengan beberapa metode. Dalam penelitian ini, pengumpulan data dilakukan dengan menggunakan metode tes.

Metode analisis data yang digunakan dalam penelitian ini adalah deskriptif kuantitatif. Data yang berupa hasil karya siswa dianalisis secara deskriptif kuantitatif, yaitu dengan cara penskoran. Analisis data secara deskriptif kuantitatif adalah analisis dan penyajian data dengan menggunakan angka-angka atau berdasarkan statistik, (Zuriah, 2006).

Tingkatkan hasil belajar PKn pada siswa kelas XI SMKN 1 Sukawati, dapat ditentukan dengan membandingkan $\mathrm{M}(\%)$ rata-rata persen ke dalam PAP skala lima dengan kriteria yang tersaji pada Tabel 3.1 .

Tabel 3.1 Pedoman PAP Skala Lima

\begin{tabular}{cc}
\hline Persentase & Kriteria \\
\hline $90-100$ & Sangat tinggi \\
$80-89$ & Tinggi \\
$65-79$ & Sedang \\
$55-64$ & Rendah \\
$0-54$ & Sangat rendah \\
\hline Sumber : Agung (2005:97)
\end{tabular}

Kriteria keberhasilan penerapan model Problem Based Learning dilihat dari pemecahan masalah yang berkaitan dengan demokrasi, jika siswa mendapat skor 65 ke atas, barulah tindakan yang dilakukan dalam penelitian ini dianggap berhasil

\section{Hasil dan Pembahasan}

Secara umum pelaksanaan pembelajaran di dalam kelas selama penelitian telah berlangsung sesuai dengan rencana pembelajaran yang telah disusun. Hasil penelitian yang disajikan pada bagian ini adalah hasil penelitian awal, penelitian siklus I, dan siklus II. Secara rinci hasil penelitian tersebut dipaparkan sebagai berikut.

Data yang digunakan sebagai data refleksi awal adalah hasil belajar sebelum pelaksanaan tindakan, yang dilaksanakan dalam pembelajaran sehari-hari. Data tersebut disajikan pada Tabel 4.1 berikut.

Tabel 4.1 Distribusi Frekwensi Hasil Penelitian Awal

\begin{tabular}{ccc}
\hline $\mathbf{X}$ & F & FX \\
\hline $\mathbf{7 0}$ & 4 & 280 \\
$\mathbf{6 5}$ & 1 & 65 \\
$\mathbf{6 0}$ & 10 & 600 \\
$\mathbf{5 5}$ & 6 & 330 \\
Jumlah & 21 & 1275 \\
\hline
\end{tabular}

Berdasarkan data pada tabel di atas, rata-rata persen hasil belajar P.Kn siswa pada refleksi awal adalah 60,71 dan ketuntasan belajar klasikal siswa adalah 28,57\%. Berdasarkan hasil nilai rata-rata hasil belajar sebesar 60,71\% kemudian dikonversikan ke PAP skala lima berada rentangan 55\%-64\%, berada pada kategori rendah. Untuk itu perlu diberikan tindakan agar hasil belajar siswa meningkat.

Pelaksanaan tindakan siklus I dalam pembelajaran adalah dengan penerapan model Problem based learning. Adapun langkah-langkah pelaksanaanya sesuai dengan prosedur tindakan yang telah dipaparkan dalam bab III bagian pelaksanaan.

Siklus I dilaksanakan selama tiga kali pertemuan, yaitu dua kali pertemuan untuk pelaksanaan tindakan dan satu kali pertemuan terakhir untuk pelaksanaan tes hasil belajar PKn, pada kompetensi Demokrasi. Pelaksanaan siklus I dilakukan sesuai dengan rencana yang dirancang. Berdasarkan hasil observasi/evaluasi terhadap pelasanaan tindakan diperoleh data seperti berikut. 
Guru masuk ke dalam kelas, seluruh siswa berdiri dan mengucapkan panganjali umat kemudian guru mengecek kehadiran siswa. Siswa mempersiapkan diri untuk mengikuti pembelajaran dengan mengeluarkan buku pelajaran PKn, buku tulis dan alat tulis. Kemudian pada tahap 1 (orientasi siswa pada masalah) kegiatan pembelajaran dilakukan dengan cara guru mengajukan beberapa pertanyaan, menyebutkan materi yang akan dipelajari serta menjelaskan tujuan pembelajaran. Tahap 2 (mengorganisasi siswa untuk belajar) kegiatan pembelajaran dilakukan oleh guru dengan membagi siswa menjadi beberapa kelompok, tiap kelompok terdiri dari 4-5 orang. Guru menugaskan kepada tiap kelompok untuk mengamati salah satu objek yang ada di lingkungan sekolah, kemudian mencatat gagasan pokok dari hasil pengamatannya. Guru memberikan waktu di luar kelas kepada siswa selama 15 menit.

Tahap 3 (membimbing penyelidikan) kegiatan pembelajaran dilakukan dengan cara pada saat siswa melakukan pengamatan di lingkungan sekitar sekolah guru berkeliling, mengantisipasi berbagai kemungkinan.

Tahap 4 (mengembangkan dan menyajikan hasil karya) kegiatan pembelajaran dilakukan dengan cara setelah semua siswa selesai membuat laporan, setiap kelompok membacakan laporannya di depan kelas.

Tahap 5 (menganalisis dan mengevaluasi proses pemecahan masalah) kegiatan pembelajaran dilakukan oleh siswa lain dan juga guru. Proses pembelajaran ditutup oleh guru dengan mengomentari pendapat siswa secara umum serta menyimpulkan materi dan diakhiri dengan guru mengarahkan agar siswa mempersiapkan diri untuk pertemuan berikutnya.

Pertemuan ke-II dilaksanakan berdasarkan hasil observasi terhadap pelasanaan tindakan diperoleh data seperti berikut. Guru masuk ke dalam kelas, seluruh siswa berdiri dan mengucapkan panganjali umat kemudian guru mengecek kehadiran siswa. Siswa mempersiapkan diri untuk mengikuti pembelajaran dengan mengeluarkan buku pelajaran PKn, buku tulis dan alat tulis. Kemudian pada tahap 1 (orientasi siswa pada masalah yang berkaitan dengan Demokrasi). Kegiatan pembelajaran dilakukan dengan cara guru mengajukan beberapa pertanyaan, menyebutkan materi yang akan dipelajari serta menjelaskan tujuan pembelajaran. Tahap 2 (mengorganisasi siswa untuk belajar) kegiatan pembelajaran dilakukan dengan cara siswa diminta untuk mengamati dan memperhatikan penjelasan guru bahwa dari hasil pengamatan siswa maka siswa akan memperoleh beberapa gagasan pokok. Kemudian, guru membagi siswa menjadi beberapa kelompok, tiap kelompok terdiri dari 4-5 orang. Guru menugaskan kepada tiap kelompok untuk mengamati salah satu objek yang ada di lingkungan sekolah, kemudian mencatat gagasan pokok dari hasil pengamatan yang digunakan sebagai dasar membuat laporan. Guru memberikan waktu di luar kelas kepada siswa selama 15 menit.

Tahap 3 (membimbing penyelidikan) kegiatan pembelajaran dilakukan dengan cara pada saat siswa melakukan pengamatan di lingkungan sekitar sekolah guru berkeliling, mengantisipasi berbagai kemungkinan termasuk menanyakan kesulitan-kesulitan siswa dalam menulis laporan.

Tahap 4 (mengembangkan dan menyajikan hasil karya) kegiatan pembelajaran dilakukan dengan cara setelah semua siswa selesai menulis laporan, setiap kelompok membacakan laporannya di depan kelas.

Tahap 5 (menganalisis dan mengevaluasi proses pemecahan masalah) kegiatan pembelajaran dilakukan dengan caramemcahkan masalah dengan mendiskusikan lapran di masing masing kelompok. Proses pembelajaran ditutup dengan guru mengomentari dan membahas dan meluruskan jawaban siswa yg kurang tepat serta menyimpulkan materi diakhiri dengan guru mengarahkan agar siswa mempersiapkan diri untuk pertemuan berikutnya.

Pertemuan ke-III, masing-masing siswa diberikan tugas. Sebelum mencapai hasil akhir.

Untuk mengetahui hasil belajar siswa dalam PKn, materi Demokrasi guru memberikan tugas unjuk kerja kepada siswa sebagai bahan evaluasi. Hasil evaluasi tersaji pada tabel distribusi frekuensi berikut.

\begin{tabular}{ccc} 
Tabel 4.2 Distribusi Frekwensi Hasil Penelitian Siklus \\
\hline $\mathbf{X}$ & $\mathbf{F}$ & $\mathbf{F X}$ \\
\hline $\mathbf{7 5}$ & 10 & 750 \\
$\mathbf{7 0}$ & 6 & 420 \\
$\mathbf{6 5}$ & 2 & 130 \\
$\mathbf{6 0}$ & 3 & 180 \\
Jumlah & 21 & 1480 \\
\hline
\end{tabular}

Berdasarkan tabel di atas, rata-rata persen hasil belajar P.Kn siswa pada siklus I adalah 70,48\% dan ketuntasan belajar klasikal siswa adalah 90,47\%. Dari hasil analisis tersebut, maka tingkatan hasil belajar siswa termasuk kategori sedang.

Data yang diperoleh ini memberikan gambaran bahwa pada siklus I hasil belajar siswa sudah mengalami peningkatan, baik dari hasil belajar individu maupun secara klasikal. Namun, dalam penelitian ini ketuntasan belajar 
secara klasikal yakni minimal sebesar $65 \%$ belum tercapai dan secara individu masih terdapat 3 orang siswa belum mencapai kriteria ketuntasan minimal.

Tindakan siklus I telah dilaksanakan sesuai dengan perencanaan. Berdasarkan analisis terhadap pemecahan masalah demokrasi yang diperoleh siswa pada tindakan I, ternyata masih ditemukan adanya kekurangan atau masalah. Kekurangan atau masalah yang dimaksud adalah beberapa siswa yang masih mendapat skor di bawah standar ketuntasan belajar.

Berdasarkan hasil refleksi pada tindakan I, perlu dilakukan perencanaan yang lebih baik untuk tindakan II. Adapun langkah-langkah pelaksanaanya sesuai dengan prosedur tindakan yang telah dipaparkan dalam bab III bagian pelaksanaan.

Pelaksanaan tindakan siklus II sesuai dengan rencana semula Pada pelaksanaan siklus II. Dalam tindakan pada siklus II ini, rincian kegiatan yang dilakukan dalam melaksanakan tindakan pada siklus II ini adalah sebagai berikut.

Pada tahap 1 (orientasi siswa pada masalah) kegiatan pembelajaran dilakukan dengan cara guru mengajukan beberapa pertanyaan, menyebutkan materi yang akan dipelajari serta menjelaskan tujuan pembelajaran. Tahap 2 (mengorganisasi siswa untuk belajar) kegiatan pembelajaran dilakukan dengan cara siswa diminta untuk mengamati ruang kelas kemudian siswa memperhatikan penjelasan guru bahwa dari hasil pengamatan siswa maka siswa akan memperoleh beberapa gagasan pokok. Kemudian, guru membagi siswa menjadi beberapa kelompok, tiap kelompok terdiri dari 4-5 orang. Guru menugaskan kepada tiap kelompok untuk mengamati salah satu objek yang ada di lingkungan sekolah, kemudian mencatat gagasan pokok dari hasil pengamatan. Dari gagasan pokok tersebut tiap kelompok menulis laporan. Guru memberikan waktu di luar kelas kepada siswa selama 15 menit.

Tahap 3 (membimbing penyelidikan) kegiatan pembelajaran dilakukan dengan cara pada saat siswa melakukan pengamatan di lingkungan sekitar sekolah guru berkeliling, mengantisipasi berbagai kemungkinan termasuk menanyakan kesulitan-kesulitan siswa dalam menulis laporan.

Tahap 4 (mengembangkan dan menyajikan hasil karya) kegiatan pembelajaran dilakukan dengan cara setelah semua siswa selesai membuat laporan, setiap kelompok melaporkan di depan kelas.

Tahap 5 yaitu menganalisis dan mengevaluasi proses pemecahan masalah dalam kegiatan pembelajaran. Proses pembelajaran ditutup dengan guru mengomentari laporan siswa secara umum serta menyimpulkan materi dan diakhiri dengan guru mengarahkan agar siswa mempersiapkan diri untuk pertemuan berikutnya.

Pertemuan ke-II, Siswa berdiri dan mengucapkan panganjali umat, dilanjutkan oleh guru untuk menyampaikan pendahuluan sebagai apersepsi.

Tahap 3 (membimbing penyelidikan) kegiatan pembelajaran dilakukan dengan cara mengajak siswa untuk mendeskripsikan beberapa masalah dan, mengantisipasi berbagai kemungkinan pemecahanya.

Tahap 4 (mengembangkan dan menyajikan hasil karya) kegiatan pembelajaran dilakukan dengan cara setelah semua siswa selesai mendeskripsikan masalah yang ditemukan, setiap kelompok melaporkan di depan kelas.

Tahap 5 (menganalisis dan mengevaluasi proses pemecahan masalah) kegiatan pembelajaran dilakukan dengan memecahkan masalah yang berkaitan dengan Demokrasi. Proses pembelajaran ditutup dengan guru mengomentari laporan dan mendiskusikannya di kelas, serta menyimpulkan materi dan diakhiri dengan guru mengarahkan agar siswa mempersiapkan diri untuk pertemuan berikutnya.

Pertemuan ke-III, masing-masing siswa diberikan tugas unjuk kerja untuk mengevaluasi hasil belajarnya. Sebelum mencapai hasil akhirdilakukan evaluasi.

Untuk mengetahui hasil belajar siswa PKn dalam kompetensi demokrasi, guru memberikan tugas unjuk kerja kepada siswa sebagai bahan evaluasi. Tugas unjuk dikerja siswa dinilai sesuai dengan kriteria penilaian yang dibuat. Hasil akhir dari tugas yang dikerjakan siswa dapat dilihat pada Tabel 4.3 berikut.

Tabel 4.3 Distribusi Frekwensi Hasil Penelitian Siklus 2

\begin{tabular}{ccc}
\hline $\mathbf{X}$ & $\mathbf{F}$ & $\mathbf{F X}$ \\
\hline $\mathbf{9 0}$ & 5 & 460 \\
$\mathbf{8 5}$ & 8 & 680 \\
$\mathbf{8 0}$ & 5 & 400 \\
$\mathbf{7 5}$ & 3 & 225 \\
Jumlah & 21 & 1765 \\
\hline
\end{tabular}

Berdasarkan data di atas diketahui bahwa dari 21 siswa, semua siswa memperoleh nilai memenuhi kriteria sehingga ketuntasan belajar klasikal (KB) pada siklus II adalah: 100\%.

Rata-rata skor hasil belajar siswa adalah 84,05\%. Rata-rata persen ini dikonversikan ke PAP skala 5 berada pada kriteria 80 - 90, yaitu berada pada kategori tinggi.

Sehingga data yang diperoleh, memberikan gambaran bahwa pada siklus II hasil belajar siswa sudah mengalami peningkatan dari siklus I dan hasil belajar siswa sudah memenuhi kriteria ketuntasan. 
Dilihat dari hasil yang dicapai siswa, pelaksanaan tindakan pada siklus I menunjukkan hasil yang sedang dan pada siklus II hasil yang diperoleh siswa lebih tinggi. Hal ini terbukti dari hasil belajar yang diperoleh siswa mengalami peningkatan yaitu dari rata-rata skor hasil belajar 70,48\% pada siklus I meningkat menjadi $\mathbf{8 4 , 0 5 \%}$ pada siklus II.

Adanya peningkatan ini tidak dapat dilepaskan dari diterapkannya model Problem based learning dalam PKn, kompetensi demokrasi di SMKN 1 Sukawati Gianyar.

Dari hasil evaluasi siswa pada siklus II, yaitu 84,05\%, berarti pelaksanaan tindakan dapat dikatakan berhasil dan penelitian dapat dihentikan. Sesuai dengan rencana awal dalam penelitian ini, yakni tindakan dinyatakan berhasil, jika $65 \%$ siswa mendapat skor 65 ke atas, dan dalam penelitian ini sudah mencapai $100 \%$ tuntas.

Peningkatan skor yang cukup baik dalam penelitian ini telah membuktikan bahwa penerapan model Problem Based Learning dapat mengefektifkan pembelajaran PKn. Hasil penelitian ini ditunjang oleh teori yang sesuai dengan pendapat Dewey (dalam Trianto, 2010:91), "Problem Based Learning adalah interaksi antara stimulus dan respons, merupakan hubungan antara dua arah, belajar dan lingkungan”.

Lingkungan memberi masukan kepada siswa berupa bantuan dan masalah sedangkan sistem syaraf otak berfungsi menafsirkan bantuan itu secara efektif sehingga masalah yang dihadapi dapat diselidiki, dinilai, dianalisis, serta dicari pemecahannya dengan baik. Pengalaman siswa yang diperoleh dari lingkungan akan menjadikan siswa untuk mendapatkan bahan dan materi guna memperoleh pengertian serta bisa dijadikan pedoman dan tujuan belajarnya. Berdasarkan uraian di atas, terbuktilah bahwa hasil belajar PKn di SMKN1 Sukawati Gianyar dapat ditingkatkan dengan penerapan model Problem Based Learning .

\section{Simpulan dan Saran}

Hasil penelitian tindakan kelas yang dilaksanakan dalam 2 siklus ini dapat disimpulkan sebagai berikut

Penerapan model Problem Based Learning pada penelitian ini ternyata dapat meningkatkan hasil belajar PKn, pada siswa kelas XI SMKN 1 Sukawti Gianyar. Berdasarkan hasil analisis yang telah dilakukan, rata-rata skor hasil belajar PKn saat pelaksanaan tindakan pada siklus I sebesar 70,48, rata-rata persen hasil belajar sebesar $70,48 \%$ termasuk dalam tingkatan hasil belajar kategori sedang. Ketuntasan belajar klasikal siswa pada siklus I mencapai $90,47 \%$.

Sedangkan rata-rata skor pada siklus II mencapai 84,05 rata-rata persen hasil belajar 84,05\% termasuk dalam tingkatan hasil belajar kategori tinggi. Ketuntasan belajar klasikal siswa pada siklus II telah mencapai $100 \%$. Dengan demikian, hasil belajar PKn pada siswa dari siklus I ke siklus II, mengalami peningkatan. Dapat disimpukan bahwa penerapan model pembelajaran Problem Based Learning dapat meningkatkan hasil belajar PKn kompetensi demokras.

Ada beberapa saran dalam penelitian ini yang ingin disampaikan . adalah sebagai berikut.

Pertama, siswa hendaknya lebih aktif dalam proses pembelajaran sehingga dapat memahami materi dengan baik, dan hasil belajar PKn dapat meningkat.

Kedua, guru pengajar agar menerapkan model Problem Based Learning untuk meningkatkan hasil belajar. Ketiga, Sekolah agar senantiasi mendorong staf guru untuk melakukan pembelajaran inovatif seperti pembelajaran berbasis masalah yang dilaksanakan dan ternyata sangat membantu siswa memahami materi pembelajaran.

Keempat, bagi peneliti lain yang ingin menerapkan model Problem Based Learning diharapkan mencermati kendala-kendala yang ditemukan, sehingga dapat dihasilkan kegiatan pembelajaran yang dapat meningkatkan hasil belajar P.Kn siswa secara optimal.

\section{Daftar Pustaka}

Agung, A. A. Gede. 2005. Metodologi Penelitian Pendidikan Suatu Pengantar. Singaraja: IKIP Negeri Singaraja. Amir, M. Taufiq. 2007. Inovasi Pendidikan Melalui Problem Based Learning : Bagaimana Pendidik Memberdayakan Pemelajar di Era Pengetahuan. Jakarta: Kencana.

Arikunto, Suharsimi dkk. 2007. Penelitian Tindakan Kelas. Jakarta: PT Bumi Aksara.

Mulyati, Yeti, dkk. 2007. Keterampilan BerP.Kn. Jakarta: Universitas Terbuka.

Rusyan, A. Tabrani, dkk. 1992. Penentuan Belajar yang Sukses. Jakarta: Nine Karya Jaya.

Trianto, 2010. Mendesain Model Pembelajarn Inovatif-Progresif: Konsep, Landasan, dan Kurikulum Tingkat Satuan Pendidikan (KTSP). Jakarta: Kencana.

Zuriah, Nurul. 2006. Metode Penelitian Sosial dan Pendidikan. Jakarta: Bumi Aksara. 